\title{
Kirkeskipet \\ - om å utvikle barnegudstjenester med barn og for barn
}

\author{
Av Stein Ellinggard, \\ sokneprest i Lademoen kirke.E-post: se778@kirken.no
}

\begin{abstract}
Den lille jenta på to år ble sittende lenge ved lysene $i$ koret. De andre barna var kommet ut $i$ våpenhuset.

Hun ville ikke gå, men satt der på alterringen sammen med Marit. Hun var stille, men så kom det. "Mamma ligger på sofaen, mamma er syk». "Skal vi tenne et lys for mammaen din», sa den voksne. "Nei», svarte jenta. Hun ville bare sitte der.
\end{abstract}

Slike opplevelser med barna er det det mange av når vi feirer gudstjenesten Kirkeskipet i Barnas katedral i Lademoen kirke. En gudstjeneste for de aller minste med øvre aldergrense tre år.

I 2018 fikk gudstjenesten Trosopplæringsprisen hvor juryen blant annet skrev: «Trosopplæringsprisen 2018 går til et arbeid som tar på alvor barn som troende spirituelle mennesker. De har utviklet en gudstjeneste som ønsker å ta barns rett til medvirkning og barns spiritualitet på alvor. Barna far møte kirken på sine egne premisser. Det gis rom for deres erfaringer, og barna far utvikle sine egne rituelle trosuttrykk. Menigheten har funnet en form for en gudstjenestefeiring hvor barna fâr utrykke seg selv, tro, tvil og tilbedelse.» (Komitéuttalelse Trosopplæringsprisen.)

I snart 5 år har denne barnegudstjenesten blitt feiret i Barnas katedral i Trondheim. Det startet som et forsøksprosjekt, men utviklet seg etter hvert til en fast gudstjeneste hvor barnehagene i byen blir invitert med jevne mellomrom. Noen av barnehagene som deltar, har utvidet kristen formålsparagraf. Noen har ikke dette, men har likevel sett det som et godt tilbud til de minste barna. Her har staben besøkt barnehagene og hatt en grundig orientering om hva gudstjenesten inneholder. Vi har også gudstjenester på lørdager som er åpne også for foreldrene. Gudstjenesten er blitt videreutviklet fra det arbeidet som teaterpedagog og frilans teaterregissør Ragnhild Steinholt har gjort sammen med barn gjennom mange år. Se blant annet hennes artikkel Kunsten å være kirke - også for små mennesker! (2003). I denne artikkelen vil jeg først kort presentere gudstjenesten. Deretter vil jeg reflektere litt over deler av innholdet og vise hvordan vi har arbeidet for at Kirkeskipet er blitt en gudstjeneste for barn på barnas egne premisser. Ønsket er å utfordre og inspirere til nytenkning. 


\section{KIRKESKIPET - EN BESKRIVELSE}

Mens kirkeklokkene ringer, ankommer barna til Lademoen kirke. I våpenhuset kler barna av seg og tar på innesko. Her møter de også noen av de som skal være med i gudstjenesten. Deretter samles alle, og presten fremsier nådehilsen. Så åpnes de store kirkedørene, og barna vandrer inn etter prosesjonskorset mens musikken spiller. Lysene er tente, og i kirken sitter flere voksne, som er frivillige og ansatte fra menigheten eller andre deler av byen. ${ }^{1}$ De fordeler seg rundt $\mathrm{i}$ kirkerommet på stoler. Kirken er ryddet slik at det skal være trygt for små barn som skal bevege seg i rommet. Rommet er pyntet som til en vanlig gudstjeneste. Et lite barnealter er satt opp ved det store hovedalteret. Det er dekket med tøystykker i kirkeårets farger og pyntet med roser. Døpefonten er fylt med litt vann, og små krakker er satt rundt, slik at det er mulig for de små å komme til. Barna får nå bevege seg fritt i rommet. Det er viktig at de voksne bare griper inn dersom det oppstår farlige situasjoner. Det er bare barnas egne stemmer som høres. Her er det alt fra gledeshyl til sår gråt. Kirkerommet tåler både krangel og «vannlek» $\mathrm{i}$ døpefonten. Barna vet at de har et fang å gå til dersom det skulle bli for mye. Denne friheten er en meget viktig del av Kirkeskipet.

Etter omtrent 20 minutter lager to voksne en «båt» i kirken. «Kom, skal vi leke!» roper den voksne og trekker et stort blått tøystykke opp midtgangen som formes til en båt. Deretter inviteres alle barna med på «fisketur». Når barna er kommet om bord, synger alle sangen «Ro, ro til fiskeskjær» og det ros med harde åretak. Så blir det imaginær fisking, og alle får være med. Etter en stund later lekerne som om de blir sultne.

På dette tidspunkt inviteres også presten, musiker og korsbærer med i båten. Så synges bordverset «Herre din jord bærer mat nok for alle». Etter bordverset tar presten den imaginære hvetebollen som rekkes til medliturgen som leser ordene over den mens hun vender seg til Kristus på prosesjonskorset. «I den natt da han ble forrådt ...» Deretter deles den imaginære maten ut til alle, og barna deler med hverandre. Det samme skjer med «vann» som øses fra sjøen, ordene leses, vannet deles ut og drikkes. Når båtsekvensen er over, hjelper barna de voksne med å dra båten på land, og tøystykket pakkes bort.

Nå blir det igjen anledning for barna til å bevege seg i rommet. De voksne trekker seg tilbake. Noen tar blomster fra barnealteret og legger kronblader i døpefonten. Andre leker med tøystykkene. Noen løper opp og ned midtgangen. Noen sitter stille på alterringen. Etter en slik sekvens starter musikken, og voksne og barn samles i koret. Her synges en felles salme. Vi har valgt en dåpssalme «Når natten har fløyet», skrevet av Gry Sveen og Øyvind Sund. Denne synges

1 Det kan være alt fra tre-fire til opp mot 25 barn som deltar. Vi har valgt å være mange voksne som deltar, både prest og medliturger, musiker og flere frivillige, samt barnehagens personale. Hver gang er det også med to «lekere» som er menighetspedagoger eller andre som har fått opplæring. 
av de voksne sammen med barna. Etter salmen går noen voksne ut og henter lys og en glassplate, mens to medliturger går til alteret og henter ned de store alterlysene. Presten går til alteret. Nå får barna hente store hvite kubbelys. De bærer dem frem og får tent lysene, mens voksne passer på. Liturgen sier «Kristus er verdens lys, og han skal også være ditt lys». Så bærer barnet lyset og setter det på glassplaten. Ofte henter barna et nytt lys og gjentar det hele. Det blir mange lys i koret. Noen barn setter seg ned og ser på lysene. Når lysseremonien er over, lyser presten velsignelsen og ringer med en liten klokke. Barna følger konsentrert med. Gudstjenesten avsluttes ved at medliturger henter vannskåler fra alteret, går til døpefonten og øser vann, og deretter følger med i resesjon.

Nede ved hoveddøren stiller prest og medliturgene seg på hver sin side ved utgangen. De kneler ned, og de som ønsker det, får tegnet et vannkors i hånden sin. Prest og medliturg sier «Gud går med deg» og lukker barnets hånd. Så går barna ut av kirkerommet, og dørene lukkes. Kirkeskipet kan vare opp mot en og en halv time. Det kan virke lenge for små barn, men når gudstjenesten er over, er det fortsatt barn som ikke vil gå. Noen sitter ved lysene, andre er opptatt med noe ved døpefonten, mens andre har funnet seg en stille krok i kirken. Ofte må liturgene stå lenge og vente til de siste barna er ute i våpenhuset og døren kan stenges.

Kirkeskipet har sin Ordo. Den består i korte trekk som følger:

\author{
Inngang med musikk \\ Frilek i omtrent 20 minutter \\ Båten som etableres, sang, lek og nattverdsfeiring \\ Frilek i omtrent 20 minutter \\ Felles samling og sang i koret \\ Lystenning \\ Velsignelse og klokkeringing \\ Utgang og korsmerking med vann
}

\title{
II KIRKESKIPET - METODISK TILNERMING
}

Å lage gode gudstjenester med barn til stede er krevende. Det er mange hensyn å ta. I en familiegudstjeneste på søndags formiddag er det mye som skal skje. Ofte er det dåp med mange voksne, og alle skal kjenne seg sett og inkludert. Dersom vi skal være selvkritiske, kan en stille spørsmålet: får de minste egentlig så mye ut av en slik time? Dekker barne- og familiegudstjenestene ofte mer de voksnes behov enn barnas? Jeg vil komme tilbake til dette spørsmålet senere i denne artikkelen. Her vil jeg nå se på Kirkeskipet, en gudstjeneste med øvre aldergrense tre år. 
Hva er viktig å tenke over når en skal lage gode barnegudstjenester? Noe av det mest grunnleggende er at det må være en gudstjeneste nettopp for barna. En god barnegudstjeneste bør ta utgangspunkt i barna, deres hverdag og liv. Det betyr at en må bli kjent med barna og utvikle en metode som gir voksne økt kompetanse om barn og om gudstjenester for denne gruppen. I arbeidet med Kirkeskipet opplever vi å ha lykkes i dette.

\section{Et levende blikk}

Når man skal lage gudstjenester for barn, må man kjenne barn. All god pedagogikk, barneteologi og liturgisk arbeid forutsetter det. Uten denne nærkontakten vil en bare ha en annenhånds kjennskap. Mange av oss som jobbet med Kirkeskipet, manglet denne erfaring $i$ arbeidet med barn fra $0-3$ år og å jobbe på denne måten. Derfor startet arbeidet i Kirkeskipet med å møte barna. Metoden med observasjon og refleksjon er lite brukt i vår kirke. En slik metode er mer brukt $i$ andre sammenhenger. Vi finner det blant annet i opplæring av barnehagepersonell. For førskolelærerutdanningen har Gerd Abrahamsen skrevet boken Et levende blikk (2004), hvor hun utvikler en metode for observasjon av barn i barnehage og familie. Metoden består av samspillobservasjon. Dette gir studentene en unik erfaring som de kan jobbe med i grupper. Det praktisk-teologiske seminar i Oslo har nå innført denne metoden for å oppøve studentene til å anlegge et barneperspektiv (Johnsen, 2007, 25). Hvor mye dette blir tatt med inn i norske menigheter, er usikkert. En av de få som i flere år har brukt metoden, er Ragnhild Steinholt. Hun skriver: «Hvis barnet allerede har et forhold til Gud når det blir født, hvordan kan vi da finne ut hvor det lille barnet befinner seg, hva barnet er opptatt av og hva som er viktig for barnet å gjøre når det skal feire gudstjeneste? Hvordan kan vi sikre at barn får utfolde seg på egne premisser? Den beste måten å finne svar på disse spørsmål er å være sammen med barn og observere dem i aksjon. Det handler om å finne og aktivt velge et barneperspektiv» (Steinholt, 2013, 43). Dette høres i utgangspunktet selvsagt ut, likevel har denne metoden fătt svært liten plass i gudstjenestearbeidet. Dette kan ha flere årsaker. Det er krevende for voksne å tre til siden og gi de små større plass. Det tar tid å være sammen med barn, og man tror man vet hva et barn trenger. Erfaringene fra å bruke metoden i Barnas katedral har vist oss at som voksen blir en satt på skolebenken igjen, når en møter de små. Her går en fra å la barna fritt utforske kirkerommet til etter hvert å utvikle en gudstjeneste ut fra observasjonene en gjør i rommet sammen med barna. Det betyr at Kirkeskipet også blir preget av hvordan kirkerommet er utformet. De første samlingene i kirken med barna bør altså bestå kun av frilek og en enkel lystenningsseremoni.

Samspillsobservasjon er krevende. Det handler ikke bare om å se barnet, men også om å se verden med barnets blikk. Hvordan ser kirken vår ut fra gulvnivå? 
Hva skjer når barna får ta kirkerommet i bruk uten at voksne styrer og bestemmer? Hvordan beveger de seg? Hva griper barnets oppmerksomhet? Hvordan kommuniserer kirkens liturgiske form med dem? Hvordan opplever barna det å tenne lys? En time med observasjon gir mye ny informasjon, og en vil oppdage det enkelte barnet på nytt i kirken. Etter gudstjenesten gis litt tid til egne notater, og man møter de andre til felles refleksjon og samtale. Det kan skrives dagboksnotat etter hver samling. Gruppen som samles, består hos oss av prester, diakon, menighetspedagoger, musikere, barnehagepersonell og frivillige. Hva har vi sett? På denne måten kan det skapes helt ny kompetanse om barn i en lokal menighet. Her blir vi ikke lenger bare tilskuere på avstand, men tar del i barnas verden på en helt ny måte. En slik metode gir oss hjelp til å lage gode gudstjenester på barns premisser.

\section{Den voksne i møte med barnet}

I Den norske kirke har det vokst frem en økt forståelse for barnets trospraksis i gudstjenesten. Trosopplæringsplanen Gud gir - vi deler (2010) har bidratt til et sterkere fokus i menigheten på barna. Likevel er vi kanskje ikke helt i mål. Vi har muligens enda et stykke å gå før vi kan si at barna fullt og helt er likestilt med voksne som troende. Dette kan skyldes den teologiske arven vi bærer på. Dagny Kaul satte allerede på 70-tallet et skarpt fokus på asymmetrien mellom barne- og voksenverden og kom med skarp kritikk mot religionspedagogikken. I artikkelen „Skjønte dere ikke at jeg må være i min Fars hus?" forteller hun om sitt arbeid i denne tiden (Kaul, 2007). Kaul mente at det døpte barnet var blitt overlatt til religionspedagogikken for å oppdras og opplæres til en voksen tro. Det var blitt objektivisert. I dag vil flere si at også barnet er et selvstendig troende subjekt på lik linje med den voksne. Religionspedagogikken i dag er opptatt av å forstå og utforske barnets egen tro og anlegge et barneperspektiv i sin forskning. Det er likevel nødvendig stadig å minne voksne om at vi kan glemme barneperspektivet.

Nærkontakten i Barnas katedral ble derfor viktig. Voksne kan ikke klare seg uten barna, og barna kan ikke klare seg uten voksne. I artikkelen Barnets betydning for Utopiproblemet (1989) understreker Kaul hvor viktig det er at vi ser hele menneskelivet som like viktig. Hun skriver: «Mennesket kan ikke forståes alene ut fra den voksnes periode i livet ... denne blir uforståelig hvis den ikke sees på bakgrunn av det tidligere liv og i lys av det kommende» (ibid:28). Vi bærer alle vår barndom med oss. I møte med barnet møter vi oss selv. I barnet møter vi vårt medmenneske som forsøker å finne sin vei i livet på samme måte som vi selv. Dette glemmer man lett, fordi tanken på utvikling er så styrende for alt. Alt skal utvikles mot noe som er større og bedre. Dette preger også vårt syn på mennesket. Professor Sven Hartmann skriver innsiktsfullt om dette i sin artikkel Noen kan og noen kan ikke-er det slik? og sier at «utviklingsperspektivet synes å innebære ideell utviklingsoptimisme: bedre og bedre dag for dag.» (Hartmann, 2008, 81.) Det er lett å tro 
at et menneske utvikler seg fra noe lite og umodent til noe fremtidig og stort. Hartmann advarer oss og sier «vi bør unngå å se på de som vokser som uutviklede og de som har stivnet både i kropp og sjel som normer for barnas modningsprosess» (ibid: 80). Et viktig perspektiv i arbeidet med barnegudstjenester er derfor å se at det lille barnet også har stor kompetanse og noe å lære voksne. Å utvikle gudstjenester for barn handler om å stille barna likt med voksne og respektere deres tro og spiritualitet. Det handler om å ha tid til å anlegge det rette perspektiv.

\section{KIRKESKIPET - EN LEKENDE GUDSTJENESTE}

\section{Gudstjenesten og leken}

En viktig del av barnas hverdag er leken. Den er sentral i deres utvikling. Pedagogen Hans Holter Solhjel sier det slik «at leken gir en opplevelse av det som kalles «flyt» hvor barnet opplever at hun har liten indre motstand, at de glemmer seg selv og bare er til stede i aktiviteten de holder på med. Det gir en sterk opplevelse av frihet og utfoldelsesmulighet» (Solhjel, 2015, familielab.no). Derfor lekes det i Kirkeskipet gjennom hele gudstjenesten. Barna tar rommet i bruk ut fra sitt perspektiv. De ser detaljer voksne ikke ser. Prekestolen blir til spennende rom hvor de kan gjemme seg. Det går en jevn strøm av barn opp og ned trappa til prekestolen, mens de titter gjennom åpningene i rekkverket og roper: Hei! Under prekestolen finner de en beskyttende og trygg hule. Bak alteret kan de skjule seg. De løper rundt alteret eller nedover midtgangen. Leken tar ulike former. I leken er fantasien, det imaginære, helt sentralt. Denne evnen er mye større hos barn enn hos voksne. Dette er det viktig å ta hensyn til. Det er en døråpner inn til et annet usynlig rike. «Barnets åpenhet og fantasi åpner for verdener som den tørre rasjonalisme aldri kan gripe. For barnet er ingenting umulig», sier prest Arne Bakken, som har skrevet boken Den hellige leken (Bakken 1994: 8).

Rommet gjør også noe med dem. Stedet taler sitt ordløse språk. Det sosiale livet $\mathrm{i}$ kirkerommet blir gjennomtrukket av det fysiske. Av bilder, av lys, av struktur, av historie, av et nærvær av Gud. Alterringen avgrenser veien inn til det hellige og blir et sted for å hvile, eller som Atle Krogstad skriver i artikkelen Hellige rom og andre rom (2013), «Alterringen inviterer den voksne til å knele, mens de yngste barna får mulighet til å reise seg opp» (ibid:21). Slik blir leken en viktig del av gudstjenesten, for leken er viktig i barnas spirituelle liv. Dette er dokumentert blant annet gjennom Steinholts arbeid med barna i helligdommen. (Steinholt 2007). Paulus sier i sin tale i Aten: «For det er i ham vi lever, beveger oss og er til» (Apg 17,28). Troen sitter også i det kroppslige. 


\section{Når voksne og barn leker sammen}

Ikke bare barn trenger å leke, også voksne kan finne det verdifult og fint. Det skjer idet båten etableres i kirkeskipet. Vi har opplevd at båten danner et tett og nært fellesskap og skaper mye glede. Metaforen med båten brukes flere ganger i bibelen (eks. Matt 13,2 og Joh 16,17), og skipet er et kjent bilde på kirken. Her møtes barn og voksne i øyehøyde. Prest og musiker inviteres med. To sanger synges. Sangen «Ro, ro din båt» er valgt, fordi sangen er gjenkjennbar fra barnehagen. Bordverset «Herre din jord bærer mat nok for alle» favner barn og menneskets situasjon over hele verden, og setter kirkeskipet og fellesskapet inn $i$ en større sammenheng. Denne sangen er nok litt vanskelig for de minste, men etter hvert lærer de melodien og noen av ordene. Alle i kirken er med og synger. Hele menigheten «ror» og «vugger». Barna lekefisker og lekespiser i båten. Som voksne kan det være vanskelig å følge med noen ganger. Der barna ser den skjulte virkelighet, ser vi ingenting. I båten feirer vi også nattverd. Innstiftelsesordene leses og de imaginære bollene og vannet deles ut. Det fikk oss til å spørre om ikke denne nattverdsfeiringen er vel så virkelig som vår feiring $i$ den vanlige høymessen? For barna er opplevelsen av å spise og å drikke sterkt nærværende i deres fantasi. Vi mottar og spiser «bollen», vi drikker «vannet» og vi deler det med andre. Slik blir denne nattverden helt åpen. Den kan oppfattes som en ren lek, men kan den også oppfattes som nattverd? For hva skal egentlig til for at det skal være en reell nattverd som feires? Også vår nattverdfeiring slik den praktiseres i vår kirke er jo egentlig en imaginær handling. Det er heller ikke her Jesu kropp og blod som rekkes oss i rent fysisk forstand. Vi rekkes symboler som vi tror at Jesus Kristus er fullt og helt til stede i. Dersom vi tror at Jesus Kristus er fullt og helt til stede i sitt ord og nær alt det skapte, slik det står i Paulus' brev til Kolosserne: «alt er skapt ved ham og til ham» (Kol.1,16), kan ikke Kristus også være nær i det skjulte, i luften som vi puster og i barnas spirituelle lek?

\section{Å leke frem nytt symbolspråk - Roseseremonien}

Det er ikke bare vi voksne som kan skape nye ritualer, det kan også barn. Det ser vi i kirkeskipet, når barna lekte frem et rituale som vi nå omtaler som «roseseremonien». Ved alteret lager vi som nevnt et mindre barnealter som blir pyntet med roser og fargerike tøystykker i kirkeårets farger. I døpefonten slår vi vann og setter frem skamler slik at barna kan klatre opp. Det som da skjer, er at barna tar rosene og bærer dem frem til døpefontene. De plukker kronbladene og legger dem i vannet eller rundt døpefonten. Dette skjer hver gang. Og vi spør om dette har noen dypere betydning? Er det en sammenheng mellom alter og døpefont? Eller er det «bare» en lek? Dagny Kaul, som er opptatt av symboler i religionens språk, mener at også «barnerelaterte symboler kan vokse fram i barns åpenbaringserfaring» (Kaul, 2007, 84). Er det slik at blant barn kan nye ritualer skapes og et nytt 
symbolspråk finne sin form? Symboler vi voksne ikke forstår, men må grunne på? Mye av symbolspråket vi har i dag og omgir oss med, er skapt av voksne for voksne. Et symbolspråk som vi forventer at barna skal tilegne seg og finne mening i. Hva om noen av disse symbolene ikke gir mening? For barna er det kanskje helt andre bilder som taler sterkere til dem. Hva om barna bringer med seg nye og friske symboler inn i verden som forteller noe nytt om Gud. Symboler vi voksne også kan bruke? Roseseremonien overrasker og forundret. Når vi dukker ned i barns verden og lar barn selv leke fritt, oppstår mye nytt og spennende.

\section{Lystenning - et hellig øyeblikk}

Det finnes øyeblikk i alles liv da vi aner et sterkere nærvær i tilværelsen. Et slikt øyeblikk kan være stillhet og lystenning i et kirkerom. Slike erfaringer setter seg i sinnet. Vi har erfart at lysstenningsseremonien sammen med barna i Kirkeskipet er et slikt øyeblikk. Barns evne til nærvær ved et slikt rituale gjør inntrykk. Her ser vi barnets spiritualitet så tydelig. Barneforsker David Hay skriver i sin bok The Spirit of The Child (2008) hva denne spiritualiteten hos barn er. I kapitlet «Spiritualitetens geografi» lister han opp flere kjennetegn (Hay, 2006, 63). Blant annet taler han om awareness-sensing (ibid:65). Awareness-sensing handler om å være til stede her og nå. Våken og bevisst. (ibid:71). Et annet område Hay nevner, er mystery-sensing, som handler om å være våken for mysteriet og om å undre seg (ibid:72). David Hay nevner dette som en egenskap hvor barn langt overgår de voksne, og referer til Margaret Donaldson. Gjennom hennes observasjoner av små barn påviser hun deres store evne til nærvær. Hun definerer denne «her og nå-bevisstheten» som «the point mode» (2006, Hay, 66). Denne evnen svekkes etter hvert som vi vokser til. Den voksne er mere fokusert på fortiden og fremtiden, og har vanskelig for å være helt og fullt i nuet. Vi beveger oss mer og mer i det hun kaller «the line mode». Denne søken etter å være $\mathrm{i}$ «the point mode» finner Donaldson igjen $\mathrm{i}$ flere religioner. Meditasjon er en slik metode hvor vi voksne igjen forsøker fă tak i mere av dette nærværet og tilstedeværelsen (ibid:67). Barna trenger ikke ulike teknikker for å være i nuet. De er til stede helt umiddelbart. Vi opplever at for de små, som har liten erfaring i å tenne lys i en kirke, er dette øyeblikk av hellighet og gudsnærvær. Vi ser den dype konsentrasjon i de små, og deres fasinasjon og engasjement. Slike handlinger kan derfor gi næring til deres spirituelle liv.

\section{$\AA ̊$ skape ny trospraksis - «å tegne Jesus»}

Vi tror med hele kroppen. Ikke minst barna Derfor må barnegudstjenestene også gi hjelp til ny trospraksis. Vann er et element som går igjen i Kirkeskipet. Det er virkelig vann i døpefonten og imaginært vann rundt båten. Vannet inngår også i et rituale ved utgangen. Ved resesjon går medliturger med vannskåler fra alteret via døpefonten. Liturgene stiller seg opp ved utgangen ved siden av prosesjons- 
korset. Her får de barn som ønsker det, bli tegnet med et vannkors i hånden, og liturgen sier ordene Gud går med deg. Liturgen lukker deretter barnets hånd. Det er flere grunner til at vi valgte dette elementet. Vi trenger hjelp til å uttrykke vår tro gjennom enkle handlinger. Korset er et sentralt tegn som minner oss om Jesus død og hans kjærlighet. Vannet minner oss om dåpen. Vann trenger alle for å leve. På denne måten får vannkorset en dyp symbolikk. De fleste barna rekker ut sine hender ved utgangen. De tegner det ofte $i$ hverandres hender og $i$ hånden til liturgen. Slike ritualer er med og gir hjelp til å tro. Det fortelles om ett av barna, at da hun skulle bade en kveld, ba hun sin mor rekke ut hånden sin. Barnet sa at hun ville «tegne Jesus» $i$ hånden hennes. Slik blir ny trospraksis utviklet og tatt med inn i hverdagen. I vår kirke er vi fattige på det som kan synliggjøre troen. Det kognitive har vært hovedfokus. Å utvikle ny trospraksis er derfor viktig også i gudstjenester for barn.

\section{KIRKESKIPET - AVSLUTNING OG OPPSUMMERING}

Jeg har gjennom de to foregående delene beskrevet Kirkeskipet og reflektert rundt arbeidet med å inkludere de minste blant oss. Hvorfor er det så viktig? Hvordan mener vi at Kirkeskipet samsvarer med dagens syn på barnet som et selvstendig troende og spirituelt medmenneske?

\section{Barn som gudstjenestedeltagere}

Er det plass for de minste barna i dagens barnegudstjenester? På det spørsmålet kan det nok sies både ja og nei. I mange sammenhenger er det mye fin involvering og aktivisering av barna, likevel kan barna ofte spille en nokså perifer rolle. Barna kan lett bli hyggelige innslag uten å bli tatt på alvor som selvstendige troende. I sin doktoravhandling "Religiøs læring $i$ sosiale praksisen» (2014) viser Elisabeth Tveito Johnsen hvordan gudstjenester sammen med barn kan involvere barn på en god måte, men også stille dem utenfor. Johnsens undersøkelse handler om gudstjenesten som læringsarena, men sier noe mer. Den gir et signal om at gudstjenester for barn ikke alltid tar barns spirituelle liv og barn som troende subjekter nok på alvor. Barna opptrer og vises frem, men er ikke med i den sentrale gudstjenestefeiringen. Vi har jobbet for at Kirkeskipet ikke skal fungere slik. Fra barna trer inn $\mathrm{i}$ kirkerommet til de går ut, er de den gudstjenestefeirende menighet, og de voksne må tre til side. Dette gir barn en unik erfaring. Med tanke på arbeidet $\mathrm{i}$ kirken for å styrke gudstjenestelivet for barn, er det derfor nødvendig å se kritisk på vår praksis og spørre om vi ikke i enda større grad må tilpasse våre gudstjenester til barna. Slik jeg ser det, må vi våge å sette barna mer i sentrum av gudstjenesten og forme gudstjenesten etter barna slik at de får en større delaktighet og eierskap. 


\section{Spiritualitet og tro}

Alle mennesker fødes med evne til å stille spørsmål og finne mening som går ut over det mere hverdagslige og oss selv, det transcendente. Dette gjelder ikke bare når vi er i stand til å formulere oss og tenke dype tanker, også de minste iblant oss har denne medfødte evnen. Barneforsker David Hay skriver at det spirituelle er «rooted in a universal human awareness; that it is really there and not just a culturally constructed illusion» (Hay, 2006, 18). I et sekularisert samfunn synes utøvelse av religion å skje i sammenhenger borte fra de fleste barns hverdag. Dersom alle mennesker fødes med denne spirituelle evnen, handler det om et helhetssyn på mennesket som vi trenger å bli mere bevisst på. Som handler om at vi trenger noe mere enn det som dekker kun de fysiologiske behov. Hele mennesket må få næring. Undringen og de store spørsmål må få mere plass, og barna må få gjøre sine egne erfaringer. Her gjelder det at kirken åpner sine dører og gir barna et trygt og godt rom å være i. Vi har muligheten til å gi barn noe som de ikke får så mange andre steder. Et hellig rom som de kan utforske sin spiritualitet i. Kunnskap om troen er viktig, derfor er det bra at vi har fått en plan for Trosopplæring, men troen sitter ikke bare i hodet, den sitter i hele kroppen. Dette gjelder ikke minst for de små.

Kirkeskipet skiller seg ut fra andre barnegudstjenester vi feirer i vår kirke, så langt jeg kjenner dem. Dette er en gudstjeneste på barnas premisser. Jeg har forsøkt å vise hvordan Kirkeskipet møter barna og respekterer dem som fullverdige troende spirituelle medmennesker. I vår praksis bør vi tenke kritisk rundt våre egne tradisjoner og teologi. Vi bør bruke leken og fantasien i gudstjenestearbeidet. La barna få utvikle sitt eget symbolspråk og sin egen trospraksis. Dette må bygge på observasjon og refleksjon om barnet i de lokale kirkerom.

Kirkeskipet er blitt til gjennom mange år. Den har krevd mye av tid og resursser. Kanskje vil noen si at dette blir for krevende for vår lille menighet. Jeg mener likevel at selve metoden og tenkningen kan brukes i alle norske menigheter. Det man trenger er at en gruppe små barn (gjerne fra en barnehageavdeling) vil være med. Dernest trenger man en stab som er åpen for å prøve dette ut i sin kirke, og noen frivillige. Det finnes mennesker i våre lokalsamfunn som har mye erfaring $i$ arbeidet med barn både i barnehage og skole, som man kan spørre.

Kirkeskipet og andre gudstjenester for barn skal ikke erstatte høymessen. Fortsatt må vi ha gudstjenester som forsøker å favne bredt i vår kirke. Erfaringene våre med barnegudstjenesten Kirkeskipet har likevel gitt tro på at denne gudstjenesten er riktig for denne aldergruppen. Kanskje kan metoden brukes også for større barn. Dette blir deres egen gudstjeneste. Vi har opplevd at gudstjenesten gir sterk tilhørighet. Som et barn sa til sin mor en dag de gikk utenfor Lademoen kirke: «Her er kirka mi mamma! Kor er kirka di?» Kirkeskipet involverer og engasjerer. 


\section{LITTERATUR:}

Abrahamsen, Gerd (2004) Et levende blikk. Oslo, Universitetsforlaget.

Bakken, Arne (1994). Den hellige leken. Oslo, Kirkerådet.

Hay, David og Nye, Rebecca (2006). The Spirit of The Child. Jessica Kingsley Publishers, London and Philadelphia.

Hartmann, Sven (2008). «Noen kan og noen kan ikke - er det slik?» I Sagberg, Sturla (red). Barnet i trosopplæringen. Pedagogiske og teologiske refleksjoner over barneteologi, spiritualitet og livssyn. Oslo, IKO-Forlaget.

Johnsen, Elisabeth Tveito (2008). «Barneteologi møter trosopplæring i gjensidig kritisk dialog». I Sagberg, Sturla (red). Barnet i trosopplæringen. Pedagogiske og teologiske refleksjoner over barneteologi, spiritualitet og livssyn. Oslo, IKO-Forlaget.

Johnsen, Elisabeth Tveito (2007). «Barnet som subjekt i trosopplæringen». I Årbok for den Norske kirke. Oslo, Kirkerådet.

Johnsen, Elisabeth Tveito (2014). Religiøs læring $i$ sosiale praksiser. Doktoravhandlingen forsvart ved Det teologiske fakultet, Universitetet i Oslo. Nr. 52 ISSN 1502-010X.

Krogstad, Atle (2013). «Hellige rom og andre rom». I Astrid Ramsfjell og Sturla Sagberg (red) Barnekultur og gudstjenestekultur. Oslo, IKO-Forlaget.

Kaul, Dagny (1989). «Barnets betydning for utopi-problemet». I Rapport for etterutdanning ved teologiske fakultet. Oslo, Universitetsforlaget.

Kaul, Dagny (2007). «Skjønte dere ikke at jeg måtte være i min Fars hus? Premisser for en grenseoppgang mellom barneteologi og religionspedagogikk.» I Elisabet Tveito Johnsen (red.): Barneteologi og kirkens ritualer. Oslo, Det praktisk teologiske seminar.

Den norske kirke (2010) Plan for Trosopplaring Gud gir - vi deler. Oslo, Kirkerådet.

Miller, Lisa (2015). The spiritual Child. New York St. Martin Press.

Sagberg, Sturla (2015). Holistic Religious Education - is it possible? Waxmann.

Sagberg, Sturla (2008). «Skjult eller synlig spiritualitet. Trosopplæringsreformen i lys av forskning på barns spiritualitet.» I Sturla Sagberg (red) Barnet i trosopplæringen. Oslo, IKO-Forlaget.

Solhjel, Hans Holter, se https://famlab.no/2015/11/09/lekens-betydning-forbarn-2/

Steinholt, Ragnhild (2013). «Kunsten å være kirke - også for små mennesker!» I Astri Ramsfjell og Sturla Sagberg (red): Barnekultur og gudstjenestekultur. Oslo IKO-Forlaget.

Steinholt, Ragnhild (2007). «Møte med et kirkerom og Speranzas reise». I Rapport fra et teaterprosjekt i Nidarosdomen 2001-2002. DMMH'publikasjoner. Trondheim: DMMH. 